\title{
BALANCED SCORECARD AS A TOOL FOR APPLICATION OF EU ASSISTANCE INTO INNOVATIVE DEVELOPMENT OF TOURIST COMPANIES
}

\author{
BEATA WIERZBICKA, ${ }^{1}$ JĘDRZEJ STRUMIŁŁO ${ }^{2}$
}

University of Gdańsk, Faculty of Management, POLAND

${ }^{1}$ e-mail: wierzbickabeata@02.pl

2 e-mail: jstrumillo@wp.pl

RECEIVED
ACCEPTED
JEL
CLASSIFICATION

KEYWORDS

ABSTRACT
18 January 2018

2 September 2018

$\mathrm{L} 26, \mathrm{~L} 83, \mathrm{Z} 32$

Balanced Scorecard, tourism, European Union funds

Staying on the market in a turbulent environment requires tourism companies to be flexible in their activities and abilities to anticipate the direction of those activities. In order to achieve and maintain long-term profitability, companies must determine and implement adequate strategies as well as asses them in accordance with appropriate criteria. In the work, the authors present the Balanced Scorecard (BSC) as a tool for application of EU assistance into the process of innovative development of a tourism company. Inspiring to examine the investigated company from four different perspectives, the results of the company's activity have been presented via a balanced system of BSC indicators.

\section{Introduction}

The varied generic structure of the needs reported by tourists has specific implications in the sector of tourism management. Tourism is nowadays a way of life for a man, a way of realizing various values by him, a way of experiencing the world. 
Tourism is also an economic phenomenon. It is organized by tourism enterprises offering services that are the source of their development and expansion of the profit zone. Success requires the ability to balance between strategic and operational thinking. Tourism enterprises must constantly balance the time and resources devoted on the one hand to increasing the use of service potential, and, on the other hand, to develop the brand and establish a strategic course (Pender, Sharpley, 2008, p. 139).

Development of technology creates and stimulates development of a number of new products, which the companies that are seeking to strengthen their market position must observe and try to capitalize on by implementation - which, in turn, requires significant financial investments.

Assistance provided as part of the sectoral policy is one of the most prominent forms of business support (particularly in the SME sector) in the European Union. The effect of that support should involve improvement of the condition of companies, manifested through growth in size or investments in innovations. As a result, the financial resources for companies are to be translated into a set of logically related cause and effect relationships defining the effectiveness and efficiency of operations.

The Balanced Scorecard, created by D. Kaplan and R. Norton has become an objective tool for measuring the effectiveness of a company's activity (Kaplan, Norton, 2002). This concept, as a method of strategic management, is increasingly disseminated among practitioners who see measurable benefits in the development and implementation of this idea. Inspiring an enterprise from four different perspectives (financial, customer, dynamic, operational) allows analyzing the company's performance through a new, balanced indicator system.

The study uses this method to assess the effectiveness of managing the process of allocating EU funds to the development of tourism enterprises presented in the case study.

\section{Structural funds as a form of supporting enterpprise development, as part of the EU assistance}

Most organizations - regardless of the form, type and subject of their activity - are forced to look for external sources of financing. These funds are needed for both operational activities and development projects in considerable amounts.

Since 2004, Poland has been a member of the European Union, which co-funds the projects implemented as part of the EU policy and with cooperation of the EU. Effective use of the funds obtained for implementation of these projects depends, in large part, on selection of an appropriate planning method.

The main tool for conducting both the European Union's cohesion policy as well as other types of community policies are various programs and instruments of financial support, many of which are described as the regional policy of the European Union. The instrument for implementation of the EU regional policy are the EU structural funds, the role of which is to increase the social and economic cohesion of the member states, through realization of the priority objectives set by the EU policy. The effective programming and implementation of structural funds is determined by the relevant programming principles as well as specific EU procedures for financial management, control, monitoring and evaluation. In the 2007-2013 perspective, Polish enterprises have made significant use of the opportunities offered under non-repayable financing. Year 2004 initiated a new EU perspective and created new opportunities for financing the development of enterprises from European funds. ${ }^{1}$

\footnotetext{
${ }^{1}$ An important change in the process of distributing the EU funds is the increase in the role of the so-called repayable financial instruments (loan funds and seed capital funds) played in financing the development of enterprises. Under the EU cohesion policy, this
} 
For the years 2014-2020, more than 80 billion Euro has been allocated to Poland for realization of socioeconomic cohesion. During this period, subsidies for enterprises should be aimed at building links with the sphere of science, so that the Polish economy will increasingly rely on innovation rather than imitation.

As part of the cohesion-policy funds, 6 national programs will be implemented, including a supraregional one for the provinces in Eastern Poland. A proposal for allocation of the funds within the national programs has been presented in Table 1.

Table 1. Proposal of EU funds allocation in 2014-2020 for national programs

\begin{tabular}{lc}
\hline \multicolumn{1}{c}{ Program } & Allocation, after conversion to the current prices (million Euro) \\
\hline Infrastructure and Environment & $27,513.9$ \\
Intelligent Development & $8,614.1$ \\
Knowledge Education Development & $4,419.3$ \\
Eastern Poland & $2,117.2$ \\
Digital Poland & $2,255.6$ \\
Technical Support & 700.1 \\
\hline Total & $45,620.1$ \\
\hline
\end{tabular}

Source: own elaboration on the basis of the data from the Ministry of Infrastructure and Development, www.mir.gov.pl/fundusze/fundusze_europejskie (29.09.2017).

In addition to the national programs, just as in the previous years, implementation of 16 regional programs has been anticipated. In the new perspective, there will be more decentralization in the use of EU assistance. It envisages that most of the resources within the structural funds will be managed at the regional level.

In the process of effective implementation of structural funds, it is necessary to emphasize the importance of appropriately prepared projects ${ }^{2}$ that fit well with program documents and ensure the creation of favorable conditions for innovative enterprise development. Correct justification of the project's implementation means ensuring compliance of the project's objectives and results with such strategic documents as development strategies of the country, region, commune, development strategies of the given industry in the EU, in the country, in the region; or correspond with smart region's specialties. This fact enforces the use of modern management concepts, adequate to the challenges of the modern knowledge-based economy.

\footnotetext{
type of instruments plays an increasingly important role, due to their renewability and ability to force project management efficiency. Renewability means, in this case, that the loans granted to enterprises are repaid and the repaid funds can provide support for other entities. Additionally, the potential beneficiary must plan the structure of the expenses included in the business concept of the venture, as to be able to repay the all the loaned capital. In the debt financing model, the beneficiaries in Poland can primarily use the loan funds, which have been capitalized with public funds and the credit offers within the "Credit for technological innovations" financed by the Operational Program of Innovative Development 2014-2020 (Kasprzak, 2016, p. 46).

2 The project includes a set of activities undertaken in order to achieve clearly defined objectives within a given time and with the help of the budget allocated to it (Trocki, Grucza, 2007, p. 13).
} 


\section{Strategic management as a carpier of the benefits for the tourists and tor the companies providing tourist services}

Motivations of the modern tourist are characterised by a large individualism and the search for various attractive forms of high-standard recreation. Media, in particular the Internet, have a great impact on it. A special role is played by various types of events (fairs, cultural and sports events) on which it is supposed to be, as well as theme parks, science and technology parks, the visit of which forces the developing civilization of knowledge (Weiermair, Mathies, 2004, pp. 96-98).

The needs of the tourists, depending on the purpose of their travel and on the values desired by them, are very diversified. Satisfaction of these needs is the source of the product offer of the entities functioning on the supply side. The tourist offer should be seen as a process realized by different sectors of the economy, also functioning outside the tourism sphere. Taking into account the process (and its elements) of providing services in a tourist enterprise and their connections with the environment, we can distinguish (Sławińska, 2002, p. 24):

- entrepreneurial functions related to the preparation and launch of new products for sale (both individual services, as well as benefit packages), discovery of market niches,

- operational functions, the essence of which is expressed in taking steps leading to transforming the resources at the disposal of the economic entity from tourist products,

- marketing functions related to reaching the buyers with the offer and supporting its sale.

These functions are aimed at achieving the assumed goals, and whether the goals will be achieved by the tourist enterprise, the effectiveness of management and the market verifying the tourism products offered by the entity decide.

The company must therefore strive to optimize the conditions of its operation. Define the directions of development by identifying, anticipating future changes and developing a strategy that makes it an organization capable of development.

Developing the concept of pro-innovative strategic changes and their implementation should be subordinate to the strategic management applied by the company. In the practice of the operation of small enterprises - and such is the case in the local tourism industry - the strategy is most often proprietary, nonformal. Strategic decisions are not made under any strict organizational procedures and are not undertaken in cooperation with subordinate employees, but they may be consulted outside the company (Olszewska, 2008, p. 34).

An enterprise must integrate its activity in such way, as to provide the customers with the goods and services that are of a high value for them. It is the customer who ultimately decides whether the product and the company connected with it will succeed, since by buying and paying he/she generates the company's profit, and, consequently, creates the basis for its development. Properly selected tools, allowing co-creation of the values in points of interaction between the company and its surroundings, become necessary in this process.

For this purpose, many companies use the Balanced Scorecard (BSC) created by R.S. Kaplan and D.P. Norton. The Balanced Scorecard is an excellent tool for describing and communicating the strategies to the customers, the co-operators, the suppliers and the employees in a consistent manner.

A strategy that lies at the root of enterprise value creation is a platform allowing companies to thrive, through successful implementation of the strategic goals. By engaging in activities in the relevant markets and building 
a competitive advantage on them, the company obtains appropriate conditions for growth and generation of higher profits, which determines the creation of value. (Doyle, 2003, pp. 66-67).

Obtaining economic benefits from business activity in the tourism sector requires financial outlays, due to high requirements of tourists in terms of the standard of services provided. Majority of enterprises - regardless the form, the type and the subject of the business activity, are forced to seek external sources of financing. If an enterprise wants to effectively use the full potential inherent in the assumptions of the EU assistance, it must maintain a proper distance from the current issues, without losing sight of the directions determined by the strategies. The Balanced Scorecard is a tool that supports the managers in this decision-making process, and, consequently, eliminates the problems associated with effective management entirely.

The Balanced Scorecard is more than just a performance measurement system. It is also a system supporting long-term implementation of the strategies for innovative organizations. The four perspectives of efficiency examination provide the executives with a universal tool for translating a company's vision and strategies into a set of logically linked efficiency measures.

The proper development of the four perspectives of BSC allows for maintaining a balance between the company's short and long-term goals, between factors affecting the results and their required level, and finally between the measures adopted as part of the assumptions. If we can describe the strategy in a more systematic way, we increase the probability of effective implementation.

Each BSC measure is embedded in a logical cause-and-effect chain connecting the desired effects of the strategy implementation with the factors stimulating these effects. The strategy map describes the process of transforming intangible assets into tangible financial effects. BSC uttering about strategy is a reliable basis for constructing an enterprise management system.

\section{Case study - Application of BSC in the project management process of EU financial assistance in the Guesthouse X}

Guesthouse $\mathrm{X}$ is located by the sea and its offer is directed to the customers preferring both family rest in the surroundings of nature and the environmental values guaranteeing mental relaxation as well as natural methods of physical rejuvenation. The Guesthouse customers can take advantage of numerous windsurfing schools, cruises on the sea, including cod fishing etc.

The Guesthouse has a capacity of 56 beds. It has 2-, 3-, 4-bed rooms of high standard (a full sanitary unit, a TV, kitchen equipment, exit to the balcony). For motorized customers, the guesthouse offers parking within an enclosed property. The guesthouse is also accessible for the disabled. Legally, the business is carried out by the company's management as a business activity.

The company received a subsidy from the European Union funds, as part of the Priority 3 - Local Development, Measure 3.4 - Microenterprises of Integrated Operational Program of Regional Development 2004-2006. Before starting the project, the guesthouse accommodated guests only in summer. Lack of sufficient own funds did not allow for modernization of the facility. This had become the main inspiration for submitting an application for a project subsidy from the EU funds, which was granted a positive decision.

The aim to be realized with the use of the subsidy was to obtain a larger number of customers and increasing the company's competitiveness. In this regard, the management planned to set up a Web portal promoting the natural and the touristic values of the Pomerania region. The Internet has allowed online booking. New customers were also 
supposed to be attracted firstly by introduction, after renovation and a partial modernization, of a new innovative product called chromotherapy (restoring the physical and mental balance of the body through appropriately selected colors). TAs part of the obtained funds, it was also planned to modernize the outdated heating system of the building and extend the tourist season for the whole year

The subsidy application determined the success factors associated, for instance, with the intention to increase the sales and the effectiveness of marketing, which includes several initiatives, each of which is aimed at a particular factor determining realization of the assumed goals. ${ }^{3}$

The total cost of the project implementation (partial extension and modernization of the facility) provided the amount of PLN 93,475.60, co-financing of the project from EU funds - the amount of $60,759.14$ (65\% of project costs).

Based on the Balanced Scorecard, an attempt was made to find mutual links between the activities undertaken as part of the project implementation, in the area of finance and market development.

Achievement of the strategic targets required integration of many partial actions, each of which was concentrated on the other factors conditioning implementation of the development strategy. As part of the financial perspective, achievement of a $6-8 \%$ growth rate in the next couple of years and a reduction of the customer service costs to the industry's best level were assumed.

The targets involved in the customer perspective were associated with creation of partnership relations with $70-80 \%$ of the company's customers, which were to be based on achievement of mutual benefits. Improvement of the quality of the service was also assumed, so all the customers would be satisfied with its level.

As part of the external processes perspective (the cycle of innovation and the operational cycle), the following targets were distinguished:

- to increase recognition of the market needs,

- to gain specialized knowledge in the field of chromotherapy and thalassotherapy,

- to implement marketing solutions that are based on creation of new markets,

- to complete the process of the resort expansion,

- to improve the on-line booking process,

- to provide high quality services.

As part of the last of the four BSC perspectives - the development perspective, such targets were set as: improvement of the staff's qualifications, employment of qualified personnel to handle the new product, linking the payroll system with the results achieved and creation of the right climate for undertaking initiatives.

The funds obtained by the company were used in accordance with the targets assumed in the subsidy application. Work on the extension and on modernization of the facility was carried out at the guesthouse, which allowed an increase of the service potential and a gradual increase of the sales of the services in the years 20082015 , at an average annual rate of $15 \%$. The increase of the sales volume was also related to the planned year-long guesthouse occupancy, which allowed elimination of seasonality in the work of the guesthouse.

A new product - chromotherapy - was introduced, which is an innovative method in the field of health tourism. The customers' interest was high. A promotional package ( $5 \%$ discount or an optional boat trip the Tricity) was

\footnotetext{
${ }^{3}$ The strategic intentions were developed on the basis of in-depth interviews with the company's executives.
} 
prepared for regular guests - which was intended to increase the sales by $75 \%$ (due to the relations with regular customers).

The launch of the Internet portal has improved the work of the staff, increased the availability of customers to book the service and purchase it.The Internet portal also allowed development of relations with the customers. Customer feedback on the internet forums and their positive opinions are an excellent additional promotion of the services at the facility, which, thanks to the obtained funding support, has increased its standards. As a result of these efforts, it was possible to decrease the costs of customer service and an increase of the profit margins for the company.

The positive result obtained have contributed to strengthening of the market position, due to a significant development of the relations with regular customers and acquisition of new ones.

An interview carried out with the owners of the Guesthouse in 2012 has confirmed the constant development of the investigated company. The owners highly valued the usefulness of BSC for the development strategies of a company that has been functioning on a demanding market of tourist services. The owners of the surveyed company are trying to keep up to date with the competitive game field, in the aspect of competitors operating on the market, their actions, in the field of introducing new products or new technologies.

The owners are also aware of the need for further incentives, allowing maintenance and development of the position on the competitive market. Taking into account the current situation of the company, both the internal and the external, as well as the possibility to exploit the opportunities lying in the surrounding environment and in the knowledge on the competitors' activities, the entrepreneurs are planning to undertake new initiatives aimed at achievement of further success in acquiring customers and in building lasting relationships with them.

\section{Final remarks}

Achieving a sustainable competitive advantage is a prerequisite for the functioning of enterprises in a longterm market economy. Competitive advantage can be achieved in relation to the environment as a result of adapting to it better than competitors through internal sources resulting from the company's resources and skills.

All strategic activities trigger a reaction on the part of the competition and therefore enterprises must consider different variants of their strategies, both in terms of long-term and short-term actions. In order to meet the customers' challenges and the increasingly tougher competition, a company must have its own development strategy. Knowledge, experience and constant improvement of skills in recognizing customer preferences and how to adapt to them (market research, tracking changes in the environment, establishing contacts with the R\&D sphere, etc.) allow managers to reduce the risk of business and develop the company according to their vision.

Under the conditions of market economy, a company's strategy determines its success. A universal tool for translation of an organization's strategy into a set of logically linked cause-and-effect relationships which determine effectiveness and efficiency of the company's activity is provided to executives by the Balanced Scorecard.

A universal tool for translating organizational strategy into a set of logically related cause and effect relationships, gives the management a Strategic Scorecard, which in the assumption of its creators is to constitute an innovative instrument or a management system that enables the improvement of the company's operations (Brzóska et al., 2012, p. 45). 


\section{References}

Brzóska, J., Karbownik, A., Kruczek, M, Szmal, A., Żebrucki, Z. (2012). Strategiczna Karta Wyników w teorii i praktyce. Gliwice: Wydawnictwo Politechniki Śląskiej.

Doyle, P. (2003). Marketing wartości. Warszawa: Felberg SJA.

Kaplan, R.S., Norton, D.P. (2002). Strategiczna Karta Wyników - Balanced Scorecard, Praktyka. Warszawa: Centrum Informacji Menedżerów.

Kasprzak, R, (2016). Fundusze unijne szansa na rozwój małych i średnich przedsiębiorstw. Budżet na lata 2014-2020. Gliwice: Helion.

Olszewska, B. (ed.) (2008). Zarządzanie strategiczne. Przedsiębiorstwo na progu XXI wieku. Wrocław: Wydawnictwo Uniwersytetu Ekonomicznego we Wrocławiu.

Pender, L., Sharpley, R. (2008). Zarządzanie turystyką. Warszawa: PWE.

Sławińska, M. (2002). Zarządzanie przedsiębiorstwem handlowym. Warszawa: PWE.

Trocki, M., Grucza, B. (2007). Zarządzanie projektem europejskim. Warszawa: PWE.

Weiermair, K., Mathies, C. (2004). The tourism and leisure industry: shaping the future. Binghampton: Haworth Hospitality Press.

www.mir.gov.pl/fundusze/fundusze_europejskie (29.09.2017).

Cite this article aS: Wierzbicka, B. Strumiłło, J. (2018). Balanced Scorecard as a tool for application of EU assistance into innovative development of tourist companies. European Journal of Service Management, 3 (27/2), 513-520. DOI: 10.18276/ejsm.2018.27/2-63. 